\title{
Recombinant Human Macrophage Inflammatory Protein-1 Beta
}

National Cancer Institute

\section{Source}

National Cancer Institute. Recombinant Human Macrophage Inflammatory Protein-1

Beta. NCl Thesaurus. Code C1467.

The recombinant form of endogenous MIP-1 beta chemokine that chemoattracts both neutrophils and monocytes, stimulates macrophages, and stimulates myelopoietic cell growth. 